Гаврилюк О. Модель використання хмаро орієнтованих технологій навчання...

УДК 378.096:004.738.5

DOI https://doi.org/10.24919/2308-4863/35-2-30

\title{
Ольга ГАВРИЛЮК,
}

orcid.org/0000-0001-9761-6511

аспірант

Інституту інформаційних технологій $і$ засобів навчання

Начіональної академії педагогічних наук України

(Київ, Україна) ol.gavryliuk@gmail.com

\section{МОДЕЛЬ ВИКОРИСТАННЯ ХМАРО ОРІЕНТОВАНИХ ТЕХНОЛОГІЙ НАВЧАННЯ ДЛЯ ФОРМУВАННЯ ПРОФЕСІЙНИХ КОМПЕТЕНТНОСТЕЙ МАЙБУТНІХ БАКАЛАВРІВ СТАТИСТИКИ}

\begin{abstract}
У статті розглянуто модель використання хмаро орієнтованих технологій для формування професійних компетентностей майбутніх бакалаврів статистики. У роботі опрацьовано поняттєву базу на основі опрацювання наукової літератури й досліджень вітчизняних $i$ зарубіжних дослідників та окреслено поняття «моделювання» та «модель». Здійснено опис авторської моделі, щзо представлена п'ятьма блоками (иільовий, кониептуальний, змістовно-організаційний, діяльнісно-технологічний та оиінювальний). Представлено мету й завдання моделі, педагогічні умови й принциипи навчання, запропоновано форми (традиційні й нетрадиційні) й методи навчання (пояснювально-ілюстративний, репродуктивний, метод проблемного викладу, частково-пошуковий, дослідницький) та описано рекомендовані засоби навчання (зокрема хмарні сервіси CoCalc i WolframAlpha). Meту моделі сформовано на основі перерахованих иілей навчання та переліку інтегральних, загальних $і$ професійних компетентностей, щзо описані в Державному стандарті вищої освіти спеціальності 112 «Статистика». Розглянуто рекомендації щзодо розширення змісту фахових дисииплін із використанням хмаро орієнтованих технологій навчання на прикладі фахової, варіативної навчальної дисиипліни "Комп'ютерна статистика», в межах якої можливо використовувати арсенал хмаро орієнтованих технологій навчання. Було виділено критерії та показники оиінювання сформованості професійних компетентностей майбутніх бакалаврів статистики й, відповідно, їх рівні - високий, достатній, базовий, низький. На основі розробленої авторської моделі використання хмаро орієнтованих технологій навчання для формування професійних компетентностей майбутніх бакалаврів статистики планується подальше дослідження у формі розроблення методики використання хмаро орієнтованих технологій навчання для формування професійних компетентностей майбутніх бакалаврів статистики.

Ключові слова: хмаро орієнтовані технологї̈ навчання, хмарні сервіси, модель, підготовка бакалаврів, бакалаври, статистика.
\end{abstract}

Olga GAVRYLIUK, orcid.org/0000-0001-9761-6511 Postgraduate Student Institute of Information Technologies and Learning Tools of National Academy of Pedagogical Sciences of Ukraine (Kyiv, Ukraine)ol.gavryliuk@gmail.com

\section{THE MODEL OF USING CLOUD-ORIENTED TECHNOLOGIES OF TRAINING FOR FORMATION OF PROFESSIONAL COMPETENCIES OF FUTURE BACHELORS OF STATISTICS}

This article considers the model of using cloud-based technologies for the formation of professional competencies of future bachelors of statistics. The paper considers the conceptual framework, based on the study of scientific literature and research of domestic and foreign researchers, and outlines the concepts of "modeling" and "model". The author's model is described, which is represented by five conceptual blocks (target, conceptual, content-organizational, activitytechnological, and evaluation). The purpose and tasks of the model, pedagogical conditions and principles of teaching are presented, the forms (traditional and non-traditional) and methods of training (explanatory-illustrative, reproductive, method of problem presentation, partial-search, research) are offered, and the recommended means of training are described CoCalc and WolframAlpha services). The purpose of the model is formed based on the listed purposes of training and the list of integral, general, and professional competencies which are described in the State standard of higher education of a specialty 112 "Statistics". Recommendations for expanding the content of professional disciplines with the use of cloud-based learning technologies on the example of a professional, variable discipline "Computer Statistics", within which it is possible to use an arsenal of cloud-based learning technologies. Criteria and indicators for assessing the formation of professional competencies of future bachelors of statistics were identified, and accordingly their 
levels - high, sufficient, basic, low. Based on the developed author's model of using cloud-based learning technologies for the formation of professional competencies of future bachelors of statistics, further research is planned in the form of developing methods for using cloud-based learning technologies for the formation of professional competencies of future bachelors of statistics.

Key words: cloud-oriented learning technologies, cloud services, model, bachelor training, bachelors, statistics.

Постановка проблеми. 3 розвитком технологій змінюються вимоги до компетентностей сучасних фахівців. Формування компетентностей, особливо професійних, $є$ важливим завданням, що покладено на заклади вищої освіти (далі - 3ВО) під час підготовки майбутніх бакалаврів, зокрема й майбутніх фахівців спеціальності 112 «Статистика».

Такі фахівці виконують різні операції щодо збору, обробки, аналізу даних, і важливо, щоб під час цих операцій вони могли використовувати різні засоби, що сприяють швидкому, якісному й вичерпному результату. До таких засобів нині активно залучені різні хмарні сервіси, що дають змогу працювати й оброблювати дані будь-де й будь-коли, делегувати повноваження доступу до даних та організовувати командну роботу.

Проте дослідження та опрацювання наукової літератури засвідчило, що питання формування професійних компетентностей, зокрема питання формування професійних компетентностей iз використанням хмаро орієнтованих технологій навчання (далі - ХОТН), не досить викладено, та, як результат, майбутні бакалаври статистики мало знайомі з хмарними сервісами, що можуть бути використані і майбутній професійній діяльності. Тому важливо в межах навчальної програми 3ВО, що здійснюють підготовку фахівців такого напряму, скоригувати навчальні плани відповідних профільних дисциплін шляхом використання ХОТН, що сприятиме набуттю практичного досвіду роботи 3 хмарними сервісами в розв'язанні реальних статистичних задач.

Аналіз досліджень. Теоретичні аспекти щодо моделювання описані в дослідженнях В. І. Арнольда, С. У. Гончаренка, В. В. Краєвського, В. М. Полонського, В. А. Штоффа й інших. Моделі й процес моделювання розглянуто в працях Н. П. Волкової, К. М. Гнезділова, С. О. Касярум, Г. У. Матушанського, О. М. Пєхоти, В. С. Пікельної та інших. Педагогічне моделювання розглядається в наукових роботах М. В. Анісімова, М. С. Кореця, 3. Ш. Каримова, В. О. Радкевич.

Мета статті полягає в розробці моделі використання хмаро орієнтованих технологій навчання для формування професійних компетентностей майбутніх бакалаврів статистики.

Виклад основного матеріалу. Розглянемо поняття «моделювання» та «модель». Як зазначає
Ю. П. Шапран, процес моделювання в сучасних умовах застосовується у всіх науках і практично на всіх етапах проведення наукових досліджень. Моделювання допомагає зробити досліджуване явище доступним до пізнання, змінити вивчення від складного до простого. Також дослідник Ю. П. Шапран висловлює думку, що моделювання в педагогіці сприяє аналізу й оцінці етапів процесу навчання, їх елементів і суб'єктів навчального процесу, спрямоване на побудову такої «ідеальної моделі», що допоможе оптимізувати безпосередньо процес навчання та підвищити його рівень результативності (Шапран, 2012).

О. В. Столяренко у власному дослідженні стверджує, що саме моделювання дозволяє спрогнозувати розвиток педагогічного процесу, спрямовує викладачів / вчителів на успішний результат навчання, сприяє засвоєнню та продуктивному застосуванню новітніх технологій, виступає як рушійна сила для покращення навчальної діяльності закладів освіти (Столяренко, 2015).

С. Г. Литвинова означує процес моделювання як обов'язкову й необхідну частину педагогічного дослідження, що потрібна для опису й вивчення процесів, зокрема інформаційних, властивостей, нововведень і закономірностей розвитку системи освіти, запровадження інформаційних технологій (Литвинова, 2015).

У Великому тлумачному словнику сучасної української мови термін «модель» окреслено як зразок, взірець (Бусел, 2005).

Модель - це «будь-який образ, аналог деякого об'єкта чи явища, який є умовним (схема, рисунок, креслення та інше) або матеріальним (макет, прототип та інше) взірцем, що в спрощеному вигляді зберігає зовнішню схожість і властивості оригіналу» (Гончаренко, 1997: 213).

В. В. Краєвський стверджує, що модель - це деякий результат абстрактного узагальнення, підсумовування практичного досвіду, а не наслідок експериментальної діяльності (Краевский, 2001).

Вітчизняний науковець В. Ю. Биков пропонує таке визначення поняття модель, як «деяке подання (аналог, образ) системи, що моделюється, в якому відбиваються, враховуються, характеризуються та можуть відтворюватися такі особливості цієї системи, які забезпечують досягнення цілей побудови й використання моделі» (Биков, 2008: 232). 
Гаврилюк О. Модель використання хмаро орієнтованих технологій навчання...

У роботах Ю. П. Шапрана. зазначено, що модель здійснює такі функції, як чітке визначення компонентів, які формують систему; схематичне й дійсне відбиття зв'язків між компонентами; інструментарій для порівняльного дослідження різноманітних процесів та явищ (Шапран, 2014).

О. М. Спірін і група вчених, що була об'єднана під його керівництвом, у спільному дослідженні виділили п'ять базових етапів педагогічного моделювання, а саме:

- розгляд проблеми побудови моделі й окреслення функцій об'єкту, що підлягає дослідженню, його ролі й безпосереднього місця в системі освіти;

- формування низки завдань, що визначають компоненти моделі, іiі дієвого функціонування та діагностування;

- виділення потрібних компонентів моделі, а також формування критеріїв для їхньої діагностики;

- побудова взаємозв'язків («логічних, функціональних, семантичних, технологічних та інших») між попередньо встановленими компонентами моделі;

- розроблення безпосередньо самої моделі й окреслення іiі динамічних змін (Спірін та ін., 2017).

Спираючись на окреслене дослідником Т. Б. Гуменюком поняття моделі як «штучно створеного об'єкта у вигляді схеми, фізичних конструкцій, знакових форм або формул, який, бувши подібним до досліджуваного об'єкта (або явища), відбиває і відтворює в простішому й узагальненому вигляді структуру, властивості, взаємозв' язки й відносини між елементами цього об'єкта» (Гуменюк, 2010: 55), було здійснено побудову моделі використання хмаро орієнтованих технологій (ХОТН) для формування професійних компетентностей майбутніх бакалаврів статистики методом утворення схеми, що відбиває мету, умови й принципи, структуру дії як цілісної системи (див. рис. 1.1).

Опрацювання, узагальнення, систематизація педагогічної та наукової літератури стало підгрунтям для описання авторської моделі використання ХОТН для формування професійних компетентностей майбутніх бакалаврів статистики й представлено у вигляді рис. 1.

Теоретичні основи розробки моделі використання ХОТН для формування професійних компетентностей майбутніх бакалаврів статистики грунтуються на структурному представлені п'яти компонентних блоків (цільовий, концептуальний, змістовно-організаційний, діяльнісно-технологіч- ний, оцінювальний) і результату, що очікується досягнути.

Цільовий компонент моделі складається 3 мети й завдань. Визначення та обгрунтування мети - базовий етап у побудові моделі використання ХОТН для формування професійних компетентностей майбутніх бакалаврів статистики. Мета сформована 3 огляду на цілі навчання та перелік компетентностей, що зазначені у відповідному Державному стандарті вищої освіти спеціальності 112 «Статистика». Досягнення мети орієнтовано через виконання окреслених завдань, що полягають у підвищенні рівня сформованості професійних компетентностей; формуванні вмінь застосовувати ХОТН для розв'язання професійних завдань. Результатом підготовки майбутніх бакалаврів статистики має стати висококваліфікований фахівець зі сформованими професійними компетентностями у відповідній галузі підготовки.

Концептуальний компонент передбачає розгляд теоретико-методологічних підходів, науковопедагогічних принципів, щоб забезпечити ефективність використання ХОТН для формування професійних компетентностей майбутніх бакалаврів статистики.

Концептуальний компонент запропонованої моделі базується на педагогічних умовах і принципах навчання.

У тлумачному словнику української мови зазначено, що умова - це фактор, що допомагає здійсненню, створенню, утворенню чогось або сприяє чому-небудь (Новий тлумачний словник, 1999: 632). У дослідженнях Н. В. Бухлової поняття «умови» розглядаються як єдність соціально-педагогічних i дидактичних фактів, що здійснюють вплив на навчальний процес, а також можливість керувати ними (Бухлова, 2008).

Словник-довідник із професійної педагогіки пропонує визначення поняття «педагогічні умови» як чинники, що сприяють здійсненню цілісного продуктивного педагогічного процесу 3 метою професійної підготовки майбутніх фахівців (Ничкало, 2000: 143).

О. Л. Дурманенко у своєму дослідженні узагальнює педагогічні умови як «особливості організації навчально-виховного процесу у вищому навчальному закладі, що детермінують результати виховання, освіти й розвитку особистості студента, об' єктивно забезпечують можливість їх досягнення» (Дурманенко, 2012).

Таким чином, педагогічні умови використання ХОТН містять:

1. Забезпечення позитивної мотивації студентів до застосування ХОТН у майбутній професій- 


\section{Цільовий компонент}

Мета використання ХОТН: формування професійних компетентностей майбутніх бакалаврів статистики Завдання:

- Підвищення рівня сформованості професійних компетентностей;

- Формування вміння застосовувати ХОТН для розв'язання професійних завдань.

\section{Концептуальний компонент}

Педагогічні умови:

- Забезпечення позитивної мотивації студенів до застосування ХОТН у майбутній професійній діяльності;

• Відбір педагогічно доцільних форм методів і засобів;

- Навчально-методичне й організаційно-технічне забезпечення навчального процесу;

- Використання групової форми взаємодії;

- Забезпечення єдності знань, умінь, навичок;

- Творче залучення студентів до навчально-дослідної роботи 3 використанням ХОТН;

- Застосування ХОТН 3 орієнтацією на міжпредметні зв'язки;

- Реалізація компетентнісного підходу до підготовки фахівців

Принципи навчання:

- Науковості;

- Систематичності й послідовності навчання;

- Зв'язку навчання з життям;

- Наочності;

- Індивідуального підходу;

- Оптимізації навчальновиховного процесу;

- Професійної спрямованості навчання;

- Зв'язку теорії з практикою;

- Співробітництва.

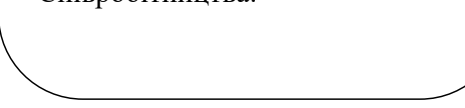

Результат: сформовані професійні компетентності майбутніх бакалаврів статистики.

\section{Змістово-організаційний компонент}

Основи роботи з ХОТН:

Здійснення обрахунків, аналізу даних, моделювання та прогнозування статистичних процесів, де можливо застосувати ХОТН.

Доповнення змісту фахових дисциплін (на прикладі «Комп'ютерна статистика») практичним розв'язанням завдань за допомогою хмарних технологій:

\section{1) CoCalc;2) WolframAlpha.}

Застосування технологій адаптивного, персоналізованого, змішаного, дистанційного, «перевернутого» навчання та технології навчальних проєктів.<smiles>C1CC2CCCC(C1)C2</smiles>

\section{Діяльнісно-технологічний компонент}

Форми: лекція, практична робота, лабораторна робота, самостійна робота.

Методи: пояснювально-ілюстративний; репродуктивний; проблемного викладу; частковопошуковий; дослідницький.

Засоби: CoCalc; WolframAlpha; підручники; ПК

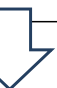

Оцінювальний компонент

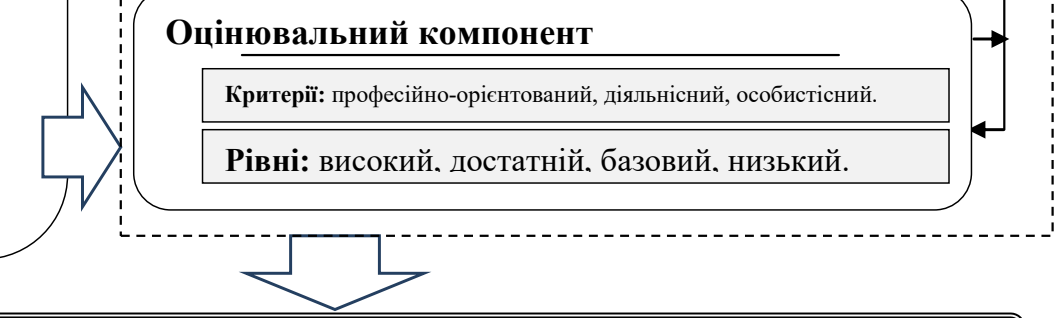

Рівні: високий, достатній, базовий, низький

\section{Рис. 1. Модель застосування ХОТН у процесі формування професійних компетентностей} майбутніх бакалаврів статистики

ній діяльності - передбачає використання ХОТН для розв'язання практичних завдань професійного спрямування та формування позитивного досвіду.

2. Відбір педагогічно доцільних форм методів і засобів, добір форм, методів і засобів навчання має базуватися на сучасних тенденціях розвитку науки й новітніх технологій, відповідати освітній програмі підготовці майбутніх фахівців і сприяти формуванню їхніх професійних компетентностей.

3. Навчально-методичне й організаційно-технічне забезпечення навчального процесу - передбачає якісний підбір навчальних матеріалів, розробку власних авторських навчальних матеріалів $\mathrm{i}$ 
Гаврилюк О. Модель використання хмаро орієнтованих технологій навчання...

матеріалів методичного супроводу, інструкційних матеріалів, добір доцільних технічних засобів.

4. Використання групової форми взаємодії використання ХОТН передбачає групову роботу, роботу в мікроколективах чи парах.

5. Забезпечення єдності знань, умінь і навичок (далі - ЗУН) - гарантується в здатності здобувачами використовувати набуті знання, уміння та навички під час навчання під керівництвом викладачів у професійних виробничих ситуаціях.

6. Творче залучення студентів до навчальнодослідної роботи з використанням ХОТН - включення провідних фахівців галузі до побудови системи практичних занять, вивчення провідного вітчизняного й світового досвіду у відповідній галузі з метою спонукання зацікавленості до організації та реалізації науково-дослідної діяльності з використанням новітніх досягнень хмарних технологій.

7. Застосування ХОТН з орієнтацією на міжпредметні зв'язки - курс на суміжні дисципліни й міжпредметні зв'язки під час добору й застосування ХОТН у процесі навчання.

8. Реалізація компетентнісного підходу до підготовки фахівців зі статистики - дотримання комплексу заходів щодо формування спеціальних (фахових) компетентностей, що окреслені держстандартом із підготовки майбутніх бакалаврів статистики.

Принципи навчання визначаються як положення, вимоги до організації та здійснення процесу навчання, що мають характер загальних правил і норм. М. М. Фіцула у своїх працях зазначає, що принципи навчання - це основні положення, які окреслюють зміст навчання, форми організації навчального процесу й методи навчання (Фіцула, 2006).

Застосування моделі використання ХОТН для формування професійних компетентностей майбутніх бакалаврів статистики допустиме за умови дотримання таких принципів навчання:

1. Науковості - цей принцип полягає в тому, що наукові факти, положення та закони, що вивчають студенти, повинні бути науково правильними. Також принцип передбачає опанування системою наукових положень і застосування наукових методів, наближених до тих, що використовує певна наука, зокрема, статистика використовує потенціал математичного апарату (Фіцула, 2006). Принцип науковості реалізовується в єдності використання програмного забезпечення та підручників, реалізації змісту навчання викладацьким складом і в підкріпленні практичними завданнями здобутих теоретичних знань (Березюк, Власенко, 2017).
2. Систематичності й послідовності навчання - в основі принципу лежить системність у роботі як викладача (здійснення посилання на попередньо вивчений матеріал під час вивчення нового, розробка системи занять / курсів, реалізація міжпредметних зв'язків), так і студентів (систематична взаємодія 3 викладачем, виконання завдань, порядок і послідовність у виконанні навчальних / практичних / творчих завдань, повторення раніше вивченого матеріалу) (Фіцула, 2006).

3. Зв'язку навчання з життям - цей принцип базується на об' єктивних зв'язках між теорією та практикою, між науковими здобутками та їх практичним галузевим застосуванням. Теоретичні знання виступають як підгрунтя продуктивної діяльності, що сприяє їхньому ефективному засвоєнню. Реалізація принципу полягає в застосуванні попереднього досвіду й практичних навичок студентів у процесі навчання (Фіцула, 2006).

4. Наочності-принцип передбачає використання залежно від характеру відбиття дійсності натуральної, зображувальної чи схематичної (схеми, діаграми, графіки) наочності (Фіцула, 2006).

5. Індивідуального підходу - в умовах колективної / групової роботи надає можливість кожному студенту на власний розсуд вивчати навчальний матеріал з урахуванням рівня розумового розвитку, їх знань і вмінь, інтересів, рівня працездатності, самостійності й вольових якостей. Потребує додаткового часу викладача на вивчення особливостей особистості студента й побудови навчальних курсів згідно з індивідуальними інтересами й схильностями й організації додаткових індивідуальних занять для студентів, які потребують допомоги в опануванні матеріалу, що вивчається в певному навчальному курсі (Фіцула, 2006).

6. Оптимізаиіі навчально-виховного процеесу - принцип базується на спеціальному свідомому доборі змісту освітньої програми, методів i форм навчання, що зможуть забезпечити найкращий результат у навчанні студентів, крім того, підбір засобів підвищення ефективності навчального процесу забезпечується шляхом підбору доцільних і відповідних до професійних ситуацій (Ягупов, 2003).

7. Принщип професійної спрямованості навчання - сутність принципу полягає у вивченні здобувачами освіти групи предметів, що тісно пов'язані з обраною майбутньою професійною діяльністю. Фактично здійснюється не навчання програмованих дисциплін, а опанування фахом. 
Результат навчання має бути відповідним до тих вимог, що постають у галузі діяльності майбутнього фахівця, саме тому під час побудови змісту освіти й підборі методів навчання у ЗВО варто спиратися на сучасні тенденції розвитку науки й виробництва, сприяти розвитку високого рівня професійних компетентностей, що зумовлюватиме конкурентоспроможність випускників закладів вищої освіти на ринку праці, гнучкість і мобільність як студентів, так і викладачів (Самарук, 2010).

8. Принщип зв'язку теорії з практикою такий принцип спрямований на процес навчання, який має спонукати здобувачів освіти застосовувати отримані знання для опанування практичних умінь і навичок, формування професійних компетентностей. Принцип грунтується на вимозі обов'язкового підкріплення теоретичного матеріалу відповідними прикладами чи реалістичними ситуаціями. Наукові теорії, знання, що закладені в зміст навчальної програми, повинні бути цілісними, а не відокремленими на часткові факти. Важливо, щоб теоретичний матеріал, поданий студентам на лекційних заняттях, базувався на їхньому попередньому досвіді з подальшим закріпленням на семінарських, практичних чи лабораторних заняттях із метою поглиблення наукових знань, формування практичних умінь і навичок та їх використання у власній майбутній професійній діяльності (Бурова, 2016).

9. Співробітництва - передбачає спільну діяльність між двома чи більше учасниками освітнього процесу з метою досягнення єдиної спільної цілі, під час якої відбувається обмін знаннями у відповідній галузі й практичним досвідом. Сприяє розв'язанню конкретних завдань чи встановленню довготривалого партнерства, що містить об'єднання ресурсів, рівність участі кожного учасника в розв'язанні поставлених навчальних чи практичних завдань і спільну відповідальність за отримані результати.

У змістовно-організаційному компоненті передбачається розгляд основ роботи 3 ХОТН; використання ХОТН для здійснення обрахунків, аналізу даних, моделювання та прогнозування статистичних процесів. Крім того, передбачається доповнення змісту фахових дисциплін практичним розв'язанням завдань за допомогою ХОТН. Реалізація доповнення змісту фахових дисциплін відбуватиметься на базі дисципліни «Комп’ютерна статистика» 3 використанням відповідних засобів ХОТН. Також передбачається застосування технологій адаптивного, персоналізованого, змішаного, дистанційного, «перевернутого» навчання та тех- нологій навчальних проєктів, що реалізовуються за допомогою ХОТН.

Діяльнісно-технологічний компонент містить ряд форм навчання, методів навчання та засобів навчання, що потребують вдосконалення шляхом використання інформаційно-комунікаційних технологій у поєднанні з практичними й лабораторними роботами, тренінгами й лекціями.

Така модель містить традиційні й нетрадиційні форми організації навчання. До них належать: лекція; практична робота; лабораторна робота; самостійна робота; тренінг; консультація; контрольна робота.

Запропонована модель передбачає застосування методів навчання:

- пояснювально-ілюстративного - передбачає сприйняття, розуміння студентами суті навчального матеріалу. Спрямований на представлення здобувачам освіти готових повідомлень, застосовуючи різні способи (словесні, наочні, практичні), а також на усвідомлення та запам'ятовування цих повідомлень ними;

- репродуктивного - метод навчання, що спрямований на відтворення студентами інформації чи практичної діяльності заздалегідь визначеним викладачем алгоритмом, який передбачає переказ матеріалу, виконання вправ за зразком, роботу за певним правилом. Метод забезпечує швидку передачу даних за короткий час, проте не сприяє розвитку гнучкості мислення;

- методу проблемного викладу - згідно із цим методом навчальний матеріал не представляється в «готовому» вигляді, викладач формує проблему й окреслює шляхи її розв'язання. Застосовують із метою розвитку навчально-пізнавальної діяльності й самостійного опанування матеріалу 3 визначеної теми;

- частково-пошукового - суть методу грунтується на викладанні частини навчального матеріалу викладачем, а інша частина матеріалу опрацьовується студентами самостійно. Орієнтиром у самостійній роботі студентів є система запитань, підготовлена заздалегідь викладачем, або система завдань для практичного розв'язання;

- досліднищького - базується на творчому застосуванні знань, опануванні методів наукового пізнання, формуванні досвіду самостійного пошуку наукових джерел та їх опрацювання. Метод раціонально використовувати під час практичної або лабораторної робіт. Проте застосування методу потребує значних часових затрат i грунтовної підготовки викладача.

Крім того, діяльнісно-технологічний компонент містить ще й засоби навчання: підручники 
(посібники, методичні рекомендації та навчальнометодичні матеріали), персональний комп'ютер чи ноутбук або смартфон / планшет із доступом до мережі Internet і спеціалізовані хмаро орієнтовані сервіси CoCalc i WolframAlpha, що були відібрані методом експертного оцінювання (Gavryliuk et al., 2020).

Оцінювальний компонент викладає критерії та рівні сформованості професійних компетентностей майбутніх бакалаврів статистики: високий, достатній, базовий і низький. Рівні сформованості визначаються на основі критеріїв та показників сформованості професійних компетентностей.

Аналіз наукової літератури дозволив виділити такі критерії професійної компетентності, як професійно орієнтований, діяльнісний та особистісний.

Професійно орієнтований критерій характеризується наявністю в майбутнього кваліфікованого фахівця теоретичної бази знань, що визначають зміст професійної діяльності.

Професійно орієнтований критерій сформованості компетентностей майбутніх бакалаврів статистики представлений такими ключовими показниками:

- опанування знаннями спеціалізованих мов програмування та прикладного програмного забезпечення;

- здатність розробляти експериментальні й спостережувальні дослідження та аналізувати дані цих досліджень;

- навички використання інформаційних i комунікаційних технологій.

Діяльнісний критерій характеризується рівнем практичного оперування набутими вміннями й навичками, що формуються під час навчальної діяльності майбутніх фахівців статистики. Професійно-теоретична база знань тісно пов'язана 3 професійними навичками реалізації практичного досвіду майбутніх бакалаврів статистики.

Діяльнісний критерій сформованості професійних компетентностей майбутніх бакалаврів статистики представлений такими ключовими показниками:

- уміння працювати з інформаційними базами даних;

- здатність до пошуку, обробки й аналізу інформації з різних джерел;

- здатність проводити дослідження ймовірнісно-статистичних моделей та інтерпретувати одержані результати;

- здатність використовувати обчислювальну техніку й програмні засоби для розв'язання задач і здобуття додаткової інформації.
Особистісний критерій розкриває сформованість особистісно-професійних якостей майбутніх статистів, які передбачають психологічні характеристики (творче мислення, уважність, наполегливість, послідовність у виконанні робочих дій, емоційна стійкість), морально-етичні характеристики (тактовність, відповідальність), психоаналітичні характеристики (самовдосконалення, об’єктивне самооцінювання), що в об'єднанні між собою мають позитивний вплив на успішність діяльності майбутнього фахівця статистики й спроможність побудови ефективних міжособистісних відносин у колективі.

Особистісний критерій сформованості професійних компетентностей майбутніх бакалаврів статистики представлений такими ключовими показниками:

- здатність працювати автономно;

- здатність працювати в команді;

- спроможність подавати статистичні процедури й результати їхнього застосування у формі, придатній для цільової аудиторії, до якої звертаються, як усно, так і письмово.

Рівні сформованості професійних компетентностей відповідають сформованості показників за визначеними критеріями.

Відповідно до зазначених показників, професійно оріснтований критерій визначається такими рівнями сформованості:

- високий - характеризується грунтовними глибокими знаннями спеціалізованих мов програмування та прикладного програмного забезпечення; здатністю самостійно розробляти експериментальні й спостережувальні дослідження та здійснювати комплексний аналіз даних цих досліджень; вільним використанням інформаційних і комунікаційних технологій у професійній діяльності.

- достатній - характеризується належним рівнем знань спеціалізованих мов програмування та прикладного програмного забезпечення; здатністю розробляти на належному рівні експериментальні й спостережувальні дослідження та здійснювати аналіз даних цих досліджень; застосуванням інформаційних і комунікаційних технологій у професійній діяльності;

- базовий - характеризується певним рівнем знань спеціалізованих мов програмування та прикладного програмного забезпечення; здатністю частково розробляти експериментальні й спостережувальні дослідження та здійснювати частковий аналіз даних цих досліджень; частковим або вибірковим застосуванням інформаційних і комунікаційних технологій у професійній діяльності; 
- низький - характеризується відсутністю належного рівня знань спеціалізованих мов програмування та прикладного програмного забезпечення; неспроможністю розробляти експериментальні й спостережувальні дослідження та здійснювати повноцінний аналіз даних цих досліджень; відсутністю навичок застосування інформаційних і комунікаційних технологій у професійній діяльності;

Відповідно до зазначених показників діяльнісний критерій визначається такими рівнями сформованості:

- високий - характеризується високим рівнем уміння працювати з інформаційними базами даних; здатністю до самостійного пошуку, обробки й грунтовного аналізу інформації з різних джерел; самостійно проводити дослідження ймовірнісно-статистичних моделей і компетентно інтерпретувати одержані результати; постійно використовувати обчислювальну техніку й програмні засоби для розв'язання задач і здобуття додаткової інформації.

- достатній - характеризується належним рівнем уміння працювати 3 інформаційними базами даних; здатністю до пошуку, обробки й обгрунтованого аналізу інформації з різних джерел; здійснювати дослідження ймовірнісно-статистичних моделей і пояснювати одержані результати; застосовувати обчислювальну техніку й програмні засоби для розв'язання задач і здобуття додаткової інформації.

- базовий - характеризується певним рівнем уміння працювати 3 інформаційними базами даних; здатністю на певному рівні до пошуку, обробки й аналізу інформації з різних джерел; частково проводити дослідження ймовірнісно-статистичних моделей і частково інтерпретувати одержані результати; частково використовувати обчислювальну техніку й програмні засоби для розв'язання задач і здобуття додаткової інформації.

- низький - характеризується відсутністю умінь працювати 3 інформаційними базами даних; відсутністю здатності до самостійного пошуку, обробки й аналізу інформації з різних джерел; під контролем проводити дослідження ймовірнісно-статистичних моделей і 3 допомогою додаткових фахівців інтерпретувати одержані результати; обмеженою можливістю використовувати обчислювальну техніку й програмні засоби для розв'язання задач і здобуття додаткової інформації.

Відповідно до зазначених показників особистісний критерій визначається такими рівнями сформованості:

- високий - характеризується високим рівнем самоорганізації, здатністю працювати автономно, без допомоги сторонніх фахівців; ефективно співпрацювати в команді; спроможністю на високому рівні подавати статистичні процедури й результати їхнього застосування у формі, придатній для цільової аудиторії, до якої звертаються, як усно, так і письмово.

- достатній - характеризується частковою здатністю працювати автономно; на відповідному рівні працювати в команді; спроможністю належним чином представляти статистичні процедури й результати їхнього застосування у формі, придатній для цільової аудиторії, до якої звертаються, як усно, так і письмово.

- базовий - характеризується потребою в контролі під час самостійного виконання професійних завдань; здатністю працювати в команді 3 порушенням делегованих повноважень; спроможністю на певному рівні подавати статистичні процедури й результати їхнього застосування у формі, придатній для цільової аудиторії, до якої звертаються, як усно, так і письмово.

- низький - характеризується здатністю працювати залежно від колег / наставників чи інших фахівців; відсутністю вмінь співпраці в команді; належних умінь подавати статистичні процедури в результати їхнього застосування у формі, придатній для цільової аудиторії, до якої звертаються, як усно, так і письмово.

Висновки. Підсумовуючи викладені факти, зазначимо, що результатом представленої моделі виступають сформовані професійні компетентності майбутніх бакалаврів статистики. Варто зазначити, що переваги презентованої авторської моделі полягають в тому, що побудова освітнього процесу базується на активному застосуванні ХОТН, розв'язанні практичних задач професійного спрямування 3 метою підготовки кваліфікованих фахівців статистики й забезпечення ринку праці конкурентоспроможними фахівцями. Перспективи подальших досліджень вбачаємо в розробленні методики використання ХОТН для формування професійних компетентностей майбутніх бакалаврів статистики. 


\section{СПИСОК ВИКОРИСТАНИХ ДЖЕРЕЛ}

1. Gavryliuk O., Vakaliuk T., Kontsedailo V. Selection criteria for cloud-oriented learning technologies for the formation of professional competencies of bachelors majoring in statistics. SHS Web of Conferences : The International Conference on History, Theory and Methodology of Learning (ICHTML 2020). Vol. 75. 04012 (2020). DOI: https://doi.org/10.1051/ shsconf/20207504012.

2. Биков В. Ю. Моделі організаційних систем відкритої освіти : монографія. Київ : Атіка, 2008. 684 с.

3. Бурова Е. В. Взаємодія теорії та практики в освітньому просторі «вищий педагогічний навчальний заклад загальноосвітня школа». Молодий вчений. Херсон, 2016. № 3. С. 362-365.

4. Бухлова Н. В. Сутнісний зміст поняття «Самоосвітня компетентність». Наукова скарбниця освіти Донеччини. Донецьк, 2008. № 1. С. 4.

5. Великий тлумачний словник сучасної української мови : 250000 / уклад. та голов. ред. В. Т. Бусел. Київ ; Ірпінь : Перун, 2005. 1728 с.

6. Гончаренко С. У. Український педагогічний словник. Київ : Либідь, 1997. 376 с.

7. Гуменюк Т. Б. Проєктування як педагогічний феномен. Науковий часопис Національного педагогічного університету ім. М. П. Драгоманова. Серія 13. Проблеми трудової та професійної підготовки. Київ, 2010. № 6. С. 51-59.

8. Дидактика: теорія і практика. Навчально-методичний посібник для студентів гуманітарних факультетів / О. С. Березюк, О. М. Власенко. Житомир : Вид-во ЖДУ ім. І. Франка, 2017. 212 с.

9. Дурманенко О. Л. Теоретичний аналіз поняття «педагогічні умови» в контексті моніторингу виховної роботи у вищому навчальному закладі. Молодь і ринок. Дрогобич, 2012. № 7. С. 135-138.

10. Краевский В. В., Полонский В. М. Методология для педагога: теория и практика. Волгоград : Перемена, 2001.324 c.

11. Моделювання й інтеграція сервісів хмаро орієнтованого навчального середовища : монографія / за заг. ред. С. Г. Литвинової. Київ : ЦП «Компринт», 2015. 163 с.

12. Новий тлумачний словник української мови: у 4 т. Київ : Аконіт, 1999. Т. 2.910 с.

13. Професійна освіта: словник : навчальний посібник / уклад. С. У. Гончаренко та. Ін ; за ред. Н. Г. Ничкало. Київ : Вища шк., 2000. 380 с.

14. Самарук Н. М. Професійна спрямованість навчання математичних дисциплін як чинник ефективного формування готовності до професійної діяльності. Вісник Національної академії Державної прикордонної служби Украӥни. Хмельницький, 2010. Вип. 2. URL: http://nbuv.gov.ua/UJRN/Vnadps_2010_2_20.

15. Спірін О. М., Яцишин А. В., Іванова С. М., Кільченко А. В., Лупаренко Л. А. Модель інформаційно-аналітичної підтримки педагогічних досліджень на основі електронних систем відкритого доступу. Інформаційні технологї $i$ засоби навчання. Київ, 2017. Вип. 3. Т. 59. С. 134-154.

16. Столяренко О. В., Столяренко О. В. Моделювання педагогічної діяльності у підготовці фахівця: навчальнометодичний. Вінниця : ТОВ «Нілан-ЛТД», 2015. 196 с.

17. Фіцула М. М. Педагогіка вищої школи : навчальний посібник. Київ : Академвидав, 2006. 352 с.

18. Шапран Ю. П. Педагогічне моделювання у процесі формування професійної компетентності майбутнього вчителя біології. Рідна школа. 2012. № 12. С. 39-43.

19. Ягупов В. В Педагогіка : навчальний посібник для студентів педагогічних спеціальностей вищих навчальних закладів. Київ : Либідь, 2003. 560 с.

\section{REFERENCES}

1. Olga Gavryliuk, Tetiana Vakaliuk, and Valerii Kontsedailo. Selection criteria for cloud-oriented learning technologies for the formation of professional competencies of bachelors majoring in statistics. ShS Web of Conferences. Vol. 75, The International Conference on History, Theory and Methodology of Learning (IChTML 2020), 04012. (2020) DOI: : https:// doi.org/10.1051/shsconf/20207504012 [in English].

2. Bykov V. Yu. Modeli orhanizatsiinykh system vidkrytoi osvity: monohrafiia [Models of organizational systems of open education]. Kyiv: Atika, 2008. 684 p. [in Ukrainian].

3. Burova E. V. Vzaiemodiia teorii ta praktyky v osvitnomu prostori "vyshchyi pedahohichnyi navchalnyi zaklad - zahalnoosvitnia shkola" [Interaction of theory and practice in the educational space "higher pedagogical educational institution - secondary school"]. Molodyi vchenyi. Kherson, 2016. № 3. pp. 362-365 [in Ukrainian].

4. Bukhlova N. V. Sutnisnyi zmist poniattia "Samoosvitnia kompetentnist" [The essence of the concept of "Selfeducational competence”]. Naukova skarbnytsia osvity Donechchyny. Donetsk, 2008. № 1. pp. 4 [in Ukrainian].

5. Velykyi tlumachnyi slovnyk suchasnoi ukrainskoi movy : 250000 [Large explanatory dictionary of the modern Ukrainian language: 250,000]/ uklad. ta holov. red. V. T. Busel. Kyiv; Irpin: Perun, 2005. 1728 p. [in Ukrainian].

6. Honcharenko S. U. Ukrainskyi pedahohichnyi slovnyk [Ukrainian pedagogical dictionary]/ S. U. Honcharenko. Kyiv: Lybid, 1997. 376 p. [in Ukrainian].

7. Humeniuk T. B. Proektuvannia yak pedahohichnyi fenomen [Design as a pedagogical phenomenon]. Naukovyi chasopys Natsionalnoho pedahohichnoho universytetu im. M. P. Drahomanova. Seriia 13. Problemy trudovoi ta profesiinoi pidhotovky.Kyiv, 2010. № 6. pp. 51-59 [in Ukrainian].

8. Dydaktyka: teoriia i praktyka [Didactics: theory and practice]. Navchalno-metodychnyi posibnyk dlia studentiv humanitarnykh fakultetiv / O. S. Bereziuk, O. M. Vlasenko. Zhytomyr: Vyd-vo ZhDU im. I. Franka, 2017.212 p. [in Ukrainian].

9. Durmanenko O. Teoretychnyi analiz poniattia "pedahohichni umovy" v konteksti monitorynhu vykhovnoi roboty u vyshchomu navchalnomu zakladi [Theoretical analysis of the concept of "pedagogical conditions" in the context of monitoring educational work in higher education]. Molod i rynok. Drohobych, 2012. № 7. pp. 135-138 [in Ukrainian]. 
10. Kraevskyi V. V. Metodolohyia dlia pedahoha: teoryia y praktyka [Methodology for the teacher: theory and practice]/ V. V. Kraevskyi, V. M. Polonskyi. Volhohrad: Peremena, 2001. 324 p. [in Russian].

11. Modeliuvannia y intehratsiia servisiv khmaro oriientovanoho navchalnoho seredovyshcha [Modeling and integration of cloud-based learning environment services]: monohrafiia / za zah. red. S. H. Lytvynovoi. Kyiv: TsP "Komprynt”, 2015. 163 p. [in Ukrainian].

12. Novyi tlumachnyi slovnyk ukrainskoi movy [New explanatory dictionary of the Ukrainian language]: u 4 t. Kyiv: Akonit, 1999. T. 2. 910 p. [in Ukrainian].

13. Profesiina osvita [Professional education]: slovnyk: navch. posib. / uklad. S. Honcharenko ta. in; za red. N. Nychkalo. Kyiv: Vyshcha shk., 2000. 380 p. [in Ukrainian].

14. Samaruk N. M. Profesiina spriamovanist navchannia matematychnykh dystsyplin yak chynnyk efektyvnoho formuvannia hotovnosti do profesiinoi diialnosti [Professional orientation of teaching mathematical disciplines as a factor in the effective formation of readiness for professional activity]. Visnyk Natsionalnoi akademii Derzhavnoi prykordonnoi sluzhby Ukrainy. Khmelnytskyi, 2010. Vyp. 2. URL: http://nbuv.gov.ua/UJRN/Vnadps_2010_2_20 [in Ukrainian].

15. Spirin O. M., Yatsyshyn A. V., Ivanova S. M., Kilchenko A. V., Luparenko L. A. Model informatsiino-analitychnoi pidtrymky pedahohichnykh doslidzhen na osnovi elektronnykh system vidkrytoho dostupu [Model of information-analytical support of pedagogical researches on the basis of electronic systems of open access]. Informatsiini tekhnolohii $i$ zasoby navchannia. Kyiv, 2017. Vyp. 3. T. 59. pp. 134-154 [in Ukrainian].

16. Stoliarenko O. V. Modeliuvannia pedahohichnoi diialnosti u pidhotovtsi fakhivtsia [Modeling of pedagogical activity in specialist training]: navchalno-metodychnyi posibnyk / O. V. Stoliarenko, O. V. Stoliarenko. Vinnytsia: TOV "Nilan-LTD”, 2015. 196 p. [in Ukrainian].

17. Fitsula M. M. Pedahohika vyshchoi shkoly [Pedagogy of high school]: navch. posib / M. M. Fitsula. Kyiv: Akademvydav, 2006. 352 p. [in Ukrainian].

18. Shapran Yu. Pedahohichne modeliuvannia u protsesi formuvannia profesiinoi kompetentnosti maibutnoho vchytelia biolohii [Pedagogical modeling in the process of forming the professional competence of a future biology teacher]. Ridna shkola. 2012. № 12. pp. 39-43 [in Ukrainian].

19. Yahupov V. V Pedahohika [Pedagogy]: navch. posib. dlia stud. ped. spets. vyshch. navch. zakl. / V. V. Yahupov. Kyiv: Lybid, 2003. 560 p. [in Ukrainian]. 